\title{
Editorial
}

\section{SOCIAL SCIENCE RESEARCH IN CANADA: The Next Step Forward}

\author{
John E. Trent, \\ Department of Political Science, University of Ottawa
}

Because of massive investments made a quarter of a century ago, Canada has provided itself with one of the largest and most capable social science communities in the world. Despite cutbacks during the past decade, a judicious development programme and adequate funding could move us into the world forefront and provide better knowledge for Canada. This article makes a broad series of proposals to help Canadian social science take this next step forward.

During their more-than-a-century of organized development in Canada, the social sciences have progressed by leaps and bounds rather than by a straight line progression. One of these leaps was in the 1960's when the number of Ph.Ds awarded went from an average of eight per year in the late 1950's to 306 doctoral degrees in 1970-71. Needless to say this reflected a similar growth in infrastructure. Expenditures on higher education from 1960 to 1970 increased at a rate nearly triple that of the GNP during the decade. By 1971 Canada was spending 9 per cent of GNP on higher education, which placed this country in first rank in the world. However, the 1970's and 80's have been a period of (perhaps necessary) consolidation, institution building, and retrenchment. In the latter regard, the extent of decline can be measured by the 25 per cent decrease in the value of research funds available to the Social Sciences and Humanities Research Council between 1974 and 1980. This is part of the general underfunding of Research and Development (R \& D) during the past 15 years in Canada when it has been consistantly near the bottom of the list of OECD countries.

The thesis of this editorial is that the means for taking the next major step forward in the development of the social sciences in Canada are at hand but that the country is acting irrationally by squandering the opportunity to maximize the return on its social science investment.

The main problem facing Canadian social scientists is the challenge of having the resources to fulfill their potential. In some cases it is a question of maintaining and developing, in other cases the requirement is for fine-tuning and maximizing output. In crude terms, we pay for salaries but not productive infrastructure; we produce graduates but not jobs; we say research is the criterion of progress but hamper it at every turn; Ottawa tries to increase research but the provinces cut back on the universities where it is done. Irrationality reigns. The fear now is 
that the public and private authorities will abandon social science in mid-stream and the country will not reap the rewards of the immense investments of the 1960's because of a lack of support for a maturing research community.

To make an approximate calculation, funding during the 'lost decade' should have been commensurate with the following factors: increased number of social scientists, 1971-80, +50\%; the increase in inflation, 1971-80, approximately + $150 \%$; the growth in maturity of the research community, 1971-80, +25\%, (judging by the growth in number of professors in the two senior ranks). Taken together one could have expected research funding to increase by $225 \%$, just to stay even with the level of resources. However total R\&D expenditures in the social sciences and humanities only grew by $115 \%$, from $1971-80$, going from $\$ 157$ millions to $\$ 336$. In comparison to natural sciences and engineering, funding expenditures on research in the social sciences and humanities declined by $2.1 \%$ between 1971 and 1980 going from $11.9 \%$ to $9.8 \%$ of gross national expenditures on research and development (Annual Review of Science Statistics, 1980 and 1981, Statistics Canada). Canadian researchers have had to adjust their research style to accommodate low levels of funding and this style is being passed on through role models to future generations. While such a style may lend itself to much academic research output that is still highly individualistic and creative, it is very counterproductive for public policy research which requires systematic, broad-gauge, interdisciplinary, longitudinal data-gathering and analysis to produce major breakthroughs.

However, it must be stressed that social science development in Canada is not just a question of increased funding. In fact, a second thesis is that increased funding should go hand-in-hand with internal improvements in the social sciences as well as better policies and management. This proposition is based on my years as a 'participant observer' in the field of social science coordination and policy-making*, and, more particularly, on two recent studies I undertook on the social sciences in Canada.

The first study, presented in May 1983 at the Unesco Conference on "Scientific and Professional Issues of Social Sciences in North America in the 1980's", commenced with an exploration of current social science issues and problems in Canada as expressed by a "mini-survey" sent to representatives of the disciplines in the Social Science Federation (SSFC) and the Social Sciences and Humanities Research Council of Canada (SSHRC) and included an historical overview of the development of the social sciences in Canada, especially during recent decades. The objective was to insert the debate over current issues into a longitudinal

\footnotetext{
* The author, aside from serving as Executive Director of the Social Science Federation of Canada from 1979-83, has been Secretary-General of the International Political Science Association, and member of the International Social Science Council and Secretary Treasurer of the Canadian Political Science Association. Most recently he was advisor to the Science Council of Canada for its first Conference on Social Science Research, Ottawa, October 1984
} 
perspective of the evolution of the social sciences in Canada to ascertain both the continuing and present requirements for their development.

The paper traced: 1) the neglect and slow development of the social sciences in Canada from the 1870's to the 1940's and 50's; 2) the rapid growth of the 1960 's with its attendant importation of training and orientations; 3 ) the consolidation and retrenchment of 1970's, and 4) the still inconclusive trends of the 1980's. The problems associated with each period were clearly delineated in 4 periodic reports made by the Social Science Federation (and its predecessor the Social Science Research Council of Canada) from 1940 to 1983, and summarized in the text. ${ }^{1}$

The second study on "Research Service Facilities in Canada" was carried out for the Social Sciences and Humanities Research Council in $1983 .^{2}$ Reporting on a small survey of senior researchers the study attempted to assess the major needs of researchers in terms of basic resources and facilities that would improve the level of research productivity.

These sources have provided the basis for the suggestions that follow with regard to the development of social science in Canada. I should also note that these suggestions are an amalgam, a sort of personal filtering, of the many proposals that have been made in state-of-the-art discussions and papers in Canada over recent years. Many colleagues should not be surprised to find their ideas reflected therein...

The proposals can be grouped together under several headings not only for greater clarity but to indicate the breadth of the measures which are required. These include: general orientations; management and coordination; funding; institutions and infrastructure; and theory and methods.

\section{General Orientations}

Maintain a balance: The overall thrust of all the following proposals is not to support one particular domaine or type of social science but to foster a high quality, creative, generalized capability in Canada. The most important longterm guideline for the social sciences is to maintain a balance between the various ingredients of which their development is composed. As trite as it is, it is also the most difficult guideline to adhere to, because there are always groups and interests, policy orientations and academic trends which tend to focus exclusive interest on priority concerns of the moment. Such tendencies should be countered. It is necessary to stress balance at this time because, although during the past three decades we have emphasized basic research and tended to ignore its relevance to

\footnotetext{
${ }^{1}$ The paper and the other studies presented at the Unesco Conference will be available in, J. Trent and P. Lamy (eds) Global Crises and the Social Sciences: North American Perspectives, University of Ottawa Press, forthcoming.

${ }^{2}$ Copies available from the Council or the author.
} 
public issues, we must continually remind those who now demand more applied output that, without an adequate continuing development of fundamental research, there will be no foundation for analysing day-to-day problems. In particular, I would single out for continuing attention balance between:

- the various disciplines;

- Canadian and comparative research;

- local, regional, national and international research;

- academic responsibilities in research, teaching and community participation;

- research production and research communication;

- applied and basic research;

- oriented and independent research;

- current issues and frontier research;

- methods, theory development and case studies;

- critical and informative research;

- creative thinking and methodological orthodoxy;

- disciplinarity and inter, multi or trans-disciplinarity.

Management and Coordination: The analysis of the social sciences in Canada has brought me inevitably to a conclusion I had not foreseen. Social Science has clearly entered a new stage in Canada and, I suspect, in the United States and other OECD countries. It is no longer just a case of needing more basic resources to allow individual social scientists to get on with their jobs. Problems are more numerous and complex. The infrastructure has been developed. Further development will depend on the effective management of the myriad balances mentioned above. When I first heard the word "management" used at a colloquium two years ago my reaction was violent. I expect most social scientists to have the same reaction now. Although one is only talking about a general and indicative planning overview that will not interfere with individual research choices (and may even improve them), "management" does not sit well with the tradition of laissez-faire. But we are now dealing with a large and complex enterprise costing more than a third of a billion dollars for research alone, without including educational expenses. We would be the first to recommend effective management for such a large scale of activity in any other sector of society.

The question is, of course, who will manage and how. It is a delicate issue and I can only give the barest suggestion here. My assumption is that the various pressures on government make it too heavy-handed an instrument to guide scientific development. Given the highly creative and individualistic nature of research, it can be assumed the heavy hand will eventually kill the goose that lays the golden egg. Also it is in the nature of scientific achievement that it is long-term. You cannot just turn the tap on and off to suit current policy priorities. The only answer I can see, then, is self-management. Presumably governments will not completely abdicate their policy role but they should be persuaded that the adequate development of selfmanagement by the research community is in the best interests of society. Canada is well placed to move in this direction because of its four decades of development of its representative social science institutions. 
To be more specific, we may consider the various objectives and functions that would be entailed in self-management, and the locales in which they might be carried out. The main objective would be to increase the number of individuals and organizations thinking about the development and coordination of social science and its component parts. Right now, it is safe to say no one thinks they have this responsibility. Who worries about obtaining additional and more diversified funding; about relations with governments and the public; about national and international problems that are not receiving enough research attention; about social science developments in other countries; or about generalized problems of theory and methodology? A partial answer is everybody and nobody. Everybody thinks about that part of the issues that fits current research interests but nobody is responsible for the broad-scale problems of developing either the infrastructure or the conceptualization of the social sciences. Cumulative results at this level are either very slow or non-existant.

The main functions include research, planning, organization, coordination, and collective projects. Mabel Timlin proposed in 1968 that there should be a clear division of functions between the Social Sciences and Humanities Research Council (than Canada Council) and the Social Science Federation. The former should handle funding, the latter, planning, research and collective initiatives. This division of functions should be recognized and supported financially by the government and the social science community. At the present time, the Council does not have a mandate for overall coordination of social science development and the Federation and its constituant associations do not have the means.

Were the Federation to accept such a responsibility, which would go beyond its current activities of lobbying, communication and coordination, one can imagine it would have to take several steps to increase its legitimacy. These might include the establishment of an advisory committee from the private and public sectors, election of officers by the entire social science community, and increased financial support from social scientists, perhaps by a salary check-off system, to be split with member associations.

It is likely a similar division of labour, between government funding councils and representative organizations of the social science community, would, in time, take hold in some provinces, especially between the Fonds FCAC and the Association canadienne française pour l'avancement des sciences (or other academic bodies) in Quebec.

One of the major functions of the Federation will have to be improved coordination with public and private sector groups that have research interests. There are just too many people who make major decisions about the social sciences without any knowledge of, or concern for, each others needs and legitimate aspirations.

Although it does not deal specifically with the social sciences, it is clear that better communication and cooperation between the federal and provincial governments and the research community would be of benefit to all disciplines. Some form of institutionalized relationship is required that builds on the realities of both provincial jurisdiction and national research concerns. One possibility is 
a joint council with a permanent secretariat to provide background studies and public consultation.

However, both these recommendations are of a centralized nature. What is equally important is to increase the number of individuals and institutions across the country that will have a broad perspective on social science development. One important solution is an increase in the number of properly financed and fully operational research institutes. A second would be to shift the position of dean away from administration and more toward the advancement of the social sciences, as is done in some leading universities in other countries. Third, national academic associations should undertake a continuing responsibility for state-ofthe-art reviews.

\section{Funding}

There are two major difficulties with social science funding: there is not enough of it and the sources are too concentrated. Social scientists must strive to develop alternate sources from foundations, the provinces, alumni, and the private sector. In particular, efforts should be made to offset in part the branch plant nature of Canada, where relatively little research is done by the private sector, by creating a Business Association for the Promotion of Research, a model that already exists in Germany.

But these alternate sources of funding will not be sufficient in themselves. Research in Canada is likely to need state support for as far as we can see into the future, in part because of the branch plant system, in part because of the relatively small population and the vast dimensions of research and territory to be covered. Unless Canada wishes to sink further and further behind in its competitive stance as a modern economy and culture, it is imperative that Ottawa and the provinces take the necessary additional steps to bring funding for $\mathrm{R} \& \mathrm{D}$ and universities up to the level of other OECD countries.

Any additional funding should be for the reinstatement of the "research time stipends" of the SSHRC and for the development of research institutes. If we are to improve research productivity in this country the primary requirements are for uninterrupted periods of research time and for concentrated research environments in which colleagues with similar interests are close at hand and where the necessary resources are available.

\section{Institutions and Infrastructures}

In Canada, universities account for a greater percentage of social science research than in most other comparable countries. It is therefore necessary that university research establishments be as competent as possible and make greater efforts to respond to the broad spectrum of social needs. These objectives require changes in personnel structures, better linkages with the public and improved research facilities. It is widely known that the main problems with personnel, problems that will haunt us for years to come, are the lack of turnover, the sex role 
imbalance and the underemployment of graduates. Here are four potential solutions :

- The Canadian Association of University Teachers, the Association of Universities and Colleges of Canada, the Council of Ministers of Education and the federal departments of Secretary of State and Employment and Immigration should immediately combine to develop and finance voluntary early retirement schemes in universities. Many of these professors could work part-or full-time for research institutes, governments and business.

- Women should be given preference in university hiring.

- Social science graduate programmes should be more oriented toward preparing students for research careers outside the university.

- Social science professors should be credited in their workload for time allocated to graduate supervision, as is done in the natural sciences. This would improve research and increase hiring.

With regard to better liaison with the public and the improvement of applied and problem-oriented research, there are a number of practical steps universities could take to improve inter-disciplinarity, research potential, development of the disciplines, research communication and exchanges:

- Social science faculties should make efforts to improve their capacity for inter-disciplinary and comparative research.

- Promotion and tenure committees should develop a careful, peersupported, university policy which recognizes and rewards high quality public awareness and communication activities.

- Research results should be developed to the 'how to do' level for public consumption.

- More universities should create research liaison offices for sustained contact with the public and private sectors.

- Either the Science Council or the Social Sciences and Humanities Research Council should sponsor studies on the utilization of social science research by government, business and the public.

Finally, our analysis of research service facilities and equipment needs concluded there are a number of emerging priority requirements for research funding in the 1980 s that are also indicative of research trends and issue areas. The top priorities are in the following categories:

- Additional means and resources to be placed at the disposal of associations, institutes and journals as the main "providers" of research services.

- A complete multi-dimensional computerized, on-line, bibliographic, documentation and abstracting service in Canadian studies, possibly based on the "Registry of Social Scientists".

- Concentration of research weight in some world class institutes with adequate full-time facilities and support personnel; when this is not feasible or desired, support should be available for national information and documentation centres in specific disciplines or fields.

- Support for "networking", including small conferences, travel, teleconferencing, computer networks, consultation and newsletters. 
- Forms of compilation, listing and access to current research and documentation.

- Advanced "office of the future" equipment and operators for efficient production, communication and dissemination.

- Capital grants for sophisticated electronic equipment for research and research-training and money for access to data banks and communications systems.

- Increased funding for publication and dissemination in both print and electronic modes.

- Specialized equipment for specific disciplines and types of research (e.g. psychology, linguistics, education, anthropology and archaeology).

\section{Theory and Methods}

Although left to the last, the improvement of social science theory and methodology is by no means the least of our concerns. Obviously it is the corner stone of all the rest, and much improvement is required. Recent social, cultural and political problems and the world economic crisis have sorely tested the foundations of theory in all disciplines. The lack of effective problem-oriented, applied methodology is also recognized. Clearly this is not just a Canadian problem, although some aspects of it are. "Organized" development of theory and methods is hard to achieve. Much of our creative theory comes from individual thinkers. But much of it also has a cumulative foundation and some methodology can be collectively developed. To help the process along, then, we can imagine several joint initiatives:

- Social Science faculties, the Social Science Federation and research institutes should multiply the number of conferences and workshops dedicated to the development of theory and methods.

- The SSHRC could promote a programme to develop applied methodology.

- All concerned, and particularly the Association of Canadian Studies, should promote conceptualization in terms of Canadian experience.

- Social scientists should not hesitate to strike out on promising new paths that might overcome current blockages in liberal marxist and other traditional approaches.

\section{Conclusion}

Some readers will argue that the above suggestions are too extensive and costly, or are not in line with traditional laissez-faire, individualist practices in the social sciences. I think we already have enough proof that despite its great achievements in recent years, history will show that social science is still in its embryonic stage. Future developments are going to require data bases, longitudinal analysis, cumulation of results, theory and method development and comparative studies, the extent of which we are already beginning to glimpse. 
At the same time, we have seen recently that the social sciences are such an important base of political and economic knowledge, and indeed, of sociopolitical criticism, that they are just no longer the concern of researchers. Nevertheless, if we are to move forward, the independence and liberty of social science research must be balanced with mechanisms for efficient development. All the above proposals have been made in this spirit.

\title{
LA RECHERCHE EN SCIENCES SOCIALES AU CANADA: vers la prochaine étape
}

\author{
John E. Trent, \\ Département de science politique, Universitẻ d'Ottawa
}

En raison des investissements massifs faits voilà un quart de siècle, le Canada s'est pourvu de l'une des plus grandes et des plus compétentes communautés du monde en sciences sociales. En dépit des restrictions budgétaires de la dernière décennie, un judicieux programme de développement et un financement adéquat pourraient nous mener à l'avant-garde mondiale et fournir une meilleure connaissance du Canada. Cet article propose une série de suggestions pour aider les sciences sociales canadiennes à faire cet autre pas en avant.

Durant plus d'un siècle de développement organisé au Canada, les sciences sociales ont évolué par bonds inégaux plutôt que par une progression régulière. Un de ceux-ci eût lieu dans les années 60 , lorsque le nombre de doctorats décernés passa de la moyenne de huit par an à la fin des années 50, à 306 en 1970-1971. Inutile de dire que ceci reflétait une croissance similaire de l'infrastructure. Les dépenses en enseignement supérieur de 1960 à 1970 atteignirent un taux équivalant presque le triple du taux d'accroissement du PNB. En 1971, le Canada dépensait 9\% du PNB en enseignement supérieur, ce qui le plaçait au premier rang mondial. Cependant, les années 70 et 80 ont été une période (peut être nécessaire) de consolidation, d'implantation institutionnelle et de restrictions budgétaires. Ces dernieres se sont manifestées par la baisse de $25 \%$ des fonds de recherche disponibles au Conseil de recherches en sciences sociales et humaines entre 1974 et 1980. Céla fait partie du sous-financement général de la Recherche et du Développement ( $R \& D$ ) durant les quinze dernières années alors que le Canada s'est retrouné pluto au bas de la liste des pays membres de l'OCDE en ce qui a trait aux fonds alloués a la $R \& D$.

L'hypothèse que cet éditorial soutient est que les moyens à prendre pour franchir cette étape importante dans le développement des sciences sociales au Canada sont à portée de la main, mais que le pays agit irrationnellement en ne saisissant pas l'occasion de tirer le maximum du rendement de son investissement dans ce domaine. 
Le principal problème des scientifiques canadiens est la course aux ressources nécessaires pour réaliser leur potentiel. Dans certains cas, c'est une question de maintien et de développement, dans d'autres, il s'agit de maximiser et adapter le rendement. En d'autres termes, nous payons des salaires mais n'investissons pas dans l'etablissement d'une infrastructure productive; nous produisons des dimlômés mais pas d'emplois; nous disons que la recherche est le critère du progrès, mais nous l'entravons à la moindre occasion; Ottawa tente d'accroître la recherche, mais les provinces font des coupures budgétaires dans les universités où elle se fait. L'irrationalité règne. On craint maintenant que les autorités publiques et privées abandonnent les sciences sociales en cours de route juste au moment où la communauté de chercheurs atteint la pleine maturité et qu'ainsi le pays ne recueille pas les fruits de l'immense investissement des années 60 .

Approximativement, le financement pendant "la décennie perdue" aurait dû être proportionnel aux facteurs suivants: l'accroissement du nombre de chercheurs en sciences sociales de 1971 à $1980:+50 \%$; l'augmentation de l'inflation de 1971 à 1980: environ 150\%; l'épanouissement de la communauté de recherche de 1971 à 1980: +25\% (basé sur l'accroissement du nombre de professeurs dans les rangs seniors). Tout cela pris ensemble, on aurait pû s'attendre à une augmentation de $225 \%$ des fonds de recherche, uniquement pour rester au même niveau. Cependant, les dépenses totales en R \& D dans les sciences sociales et humaines augmentèrent seulement de $115 \%$, soit de 157 à 336 millions de dollars entre 1971 et 1980 . Comparativement aux sciences naturelles et de la vie, les dépenses de financement des sciences sociales et humaines déclinèrent de $2,1 \%$ entre 1971 et 1980 , a savoir de $11,9 \%$ à $9,8 \%$ des dépenses nationales en recherche et développement (Annual Review. of Science Statistics, 1980 et 1981, Statistique Canada). Les chercheurs canadiens ont dû ajuster leur style de recherche pour s'accommoder des bas niveaux de financement, style qui est en train de servir de modèle aux générations futures. Tandis qu'un tel style peut s'accorder avec une recherche plutôt académique, c'est-à-dire hautement individualiste et créative, il est très improductif pour la recherche sur les politiques publiques qui requiert des données et des analyses systématiques, étendues, interdiscisplinaires et s'étendant sur de longues périodes, pour faire des percées importantes.

Cependant, il faut souligner que le développement des sciences sociales au Canada n'est pas seulement une question de financement accru. En fait, une deuxième thèse veut qu'une augmentation du financement aille de pair avec des améliorations dans les processus internes et externes qui régissent les sciences sociales. Cette proposition s'appuie sur mes années de "participant observateur" dans les domaines de la coordination des sciences sociales et de la politique scientifique et plus particulièrement, ${ }^{*}$ sur deux études que j'ai complétẻes récemment sur les sciences sociales au Canada.

La première étude, présentée en mai 1983 à la Conférence de l'Unesco sur "Les défis scientifiques et professionnelles des sciences sociales en Amérique du Nord dans les années 80 " commençaient par un inventaire des buts actuels et des 
problèmes des sciences sociales au Canada. Ceux-ci étaient exposés dans une "mini-étude" envoyée aux représentants de diverses disciplines de la Fédération canadienne des sciences sociales (FCSS) et du Conseil de recherches du Canada en sciences sociales et humaines (CRCSSH); elle comprenait aussi un historique du développement des sciences sociales au Canada, principalement durant les dernières décennies. L'objectif était d'analyser le débat sur les buts actuels, dans la perspective de l'évolution des sciences sociales au Canada afin de déterminer les exigences qui influencent leur développement.

L'article notait: 1) le développement négligé et lent des sciences sociales au Canada de 1870 à 1940 et à 1950;2) la croissance rapide des années 60 et l'importation de professeurs et des orientations scientifiques qui suivirent; 3) la consolidation et les compressions des années 70; et 4) les tendances encore peu concluantes des années 80 . Les problèmes associés à chaque époque ont été clairement décrits dans quatre rapports de la Fédération des sciences sociales (et son prédécesseur le Conseil de recherche du Canada en sciences sociales) couvrant la période de 1940 à $1983 .^{1}$

La deuxième étude, sur "Les facilités de la recherche au Canada", fut faite pour le Conseil de recherche du Canada en sciences sociales et humaines en 1983. 2 Se basant sur une petite enquête de chercheurs seniors, l'étude tentait d'évaluer les principaux besoins des chercheurs en terme de ressources fondamentales et de facilités qui permettraient d'accroître le niveau de productivité de la recherche.

Ces deux études ont fourni la base des suggestions suivantes sur le développement des sciences sociales au Canada. Je dois aussi souligner que c'est un amalgame, une sorte de filtrage personnel, des nombreuses propositions faites au Canada, ces dernières années, lors de discussions sur l'état de la discipline ou dans des articles. Plusieurs collègues ne devraient pas être étonnés de retrouver leurs idées ici...

Les propositions peuvent se regrouper sous plusieurs titres, non seulement pour plus de clarté mais aussi pour indiquer l'envergure des mesures à prendre.

${ }^{1}$ L'article et les autres études présentẻs à la Conférence de l'UNESCO seront disponibles dans: J. Trent et P. Lamy (Ed.) Global Crises and the Social Sciences: North American Perspectives, Presses de l'Université d'Ottawa, à venir.

${ }^{2}$ Des copies sont disponibles auprès du Conseil ou de l'auteur.

* L'auteur, en plus de sa fonction de directeur exécutif de la Fédération canadienne des sciences sociales de 1979 à 1983, est secrétaire général de l'Association internationale de science politique, membre du Conseil international des sciences sociales et a été secrétairetrésorier de l'Association canadienne de science politique. Tout récemment, il a été conseiller au Conseil des sciences du Canada pour sa première Conférence sur la recherche en sciences sociales, tenue à Ottawa, en octobre 1984. 
Il s'agit de: les orientations générales; la gestion et la coordination; le financement; les institutions et l'infrastructure; la théorie et les méthodes.

\section{Les orientations générales}

Maintenir l'équilibre: La tendance dominante des propositions suivantes n'est pas de supporter un domaine ou un type particulier de sciences sociales, mais d'encourager une grande compétence créatrice et générale au Canada. La ligne directrice à long terme la plus importante pour les sciences sociales est le maintien de l'équilibre entre les diverses composantes de leur développement. Aussi banal que cela paraisse; c'est aussi la ligne directrice la plus difficile à respecter parce qu'il y a toujours des groupes, des intérêts, des politiques d'orientation et des tendances académiques qui visent à concentrer exclusivement l'intérêt sur. les priorités du moment. De telles tendances devraient être contrées. Il est nécessaire actuellement d'insister sur l'équilibre car, bien que durant les trois dernières décennies, nous ayions mis l'emphase sur la recherche fondamentale et semblé ignorer ses rapports avec les objectifs publics, nous devons sans cesse rappeler à ceux qui demandent plus de résultats applicables, que sans un développement continu et adéquat de la recherche fondamentale, il n'y aura aucune base d'analyse les problèmes quotidiens. En particulier, je voudrais souligner l'équilibre à maintenir assidûment entre:

- les différentes disciplines;

- la recherche canadienne et comparative;

- la recherche locale, régionale, nationale et internationale;

- les responsabilités académiques envers la recherche, l'enseignement et la participation à la vié communautaire;

- la production et la communication en recherche;

- la recherche fondamentale et appliquée;

- la recherche orientée et indépendante;

- les buts actuels de la recherche et ses frontières;

- les méthodes, la théorie du développement et les études de cas;

- la recherche critique et informative;

- la pensée créatrice et le conformisme méthodologique;

- disciplinarité et inter-, multi-, ou trans-disciplinarité.

\section{La gestion et la coordination}

L'analyse des sciences sociales au Canada m'a amené inévitablement à une conclusion que je n'avais pas prévue. Les sciences sociales ont clairement pris une nouvelle place au Canada et, je le soupçonne, aux Etats-Unis et dans d'autres pays membres de l'OCDE. Il ne s'agit plus seulement d'un besoin de ressources permettant aux experts en sciences sociales de continuer leur recherche fondamentale. Les problèmes sont plus nombreux et complexes. L'infrastructure s'est développée. Le développement à venir dépendra de la gestion efficace de la myriade de points à équilibrer mentionnés plus haut. Lorsque pour la première fois, il y a deux ans, j'ai entendu le mot "gestion" utilisé à un colloque, ma réac- 
tion fut violente. Je m'attends à ce que plusieurs experts en sciences sociales réagissent de la même façon maintenant. Bien qu'on parle seulement de planification générale et indicative qui n'interfèrera pas avec les choix individuels de recherche (et peut même les améliorer), "la gestion" ne cadre pas bien avec la tradition de laissez-faire. Nous avons maintenant affaire à une entreprise vaste et complexe, coûtant plus d'un tiers de milliard de dollars pour la recherche seulement; ceci excluant les dépenses en éducation. Nous serions les premiers à recommander une gestion efficace pour une si vaste gamme d'activités dans n’importe quel autre secteur de la société.

Evidemment, la question est: "Qui gérera et comment?" C'est un sujet délicat et je ne peux que l'effleurer ici. Je présume que les diverses pressions agissant sur le gouvernement en font un instrument trop lourd pour diriger le développement scientifique. Etant donnée la nature hautement créatrice et individualiste de la recherche, on peut prévoir que la main lourde du gouvernement finirait par tuer la poule aux oeufs d'or. Aussi, c'est à longue échéance que se concrétisent les réalisations scientifiques. On ne peut pas changer continuellement de cap pour suivre les priorités politiques du moment. La seule réponse que je vois est donc l'auto-gestion. Les gouvernements n'abandonneront probablement pas leur rôle politique mais ils pourraient être persuadés qu'un développement adéquat de l'auto-gestion du milieu de recherche est dans le meilleur intérêt de la sociëté. Le Canada est bien placé pour embrasser cette voie en raison des quatre décennies de développement d'institutions représentant les chercheurs en sciences sociales.

Pour être plus précis, nous pouvons considérer les divers objectifs et fonctions que présume l'auto-gestion et les contextes dans lesquels elles pourraient être appliquées. Le principal objectif serait d'accroitre le nombre d'individus et d'organismes reliés au développement et à la coordination des sciences sociales et de ses composantes. $\dot{A}$ l'heure actuelle, on peut affirmer que personne ne reconnait avoir cette responsabilité. Qui s'inquiète de l'obtention de financement additionnel et diversifié? des relations entre les gouvernements et le public? des problèmes nationaux et internationaux qui ne bénéficient pas assez de la recherche? et ne retiennent pas l'attention des chercheurs? du développement des sciences sociales dans d'autres pays? ou encore des problèmes généraux de théorie et de méthodologie? La réponse partielle est: tout le monde et personne. Chacun pense aux objectifs qui vont avec ses propres intérêts de recherche mais personne n'est responsable des vastes problèmes de développement de l'infraștructure ou de conceptualisation des sciences sociales. Les résultats cumulatifs à ce niveau sont très bas sinon inexistants.

Les fonctions principales incluent la recherche, la planification, l'organisation, la coordination et les projets collectifs. En 1968, Mabel Timlin suggéra qu'il devrait $y$ avoir un net partage de fonctions entre le Conseil de recherches en sciences sociales et humaines (alors appellé le Conseil des Arts) et la Fédération des sciences sociales. Le premier devrait s'occuper du financement, la seconde de la planification, de la recherche et des initiatives collectives. Ce partage des fonctions devrait être reconnu et soutenu financièrement par le gouvernement et 
le milieu des sciences sociales. Actuellement, le Conseil n'a pas de mandat pour la coordination du développement des sciences sociales, et la Fédération et ses constituantes n'en ont pas les moyens.

Si la Fédération acceptait une telle responsabilité, laquelle irait au-delà de ses activités actuelles de lobbying, de communication et de coordination, on peut imaginer qu'elle devrait franchir plusieurs étapes pour accroître sa légitimité. Ceci pourrait comprendre la création d'un comité de consultation des secteurs privé et public, l'élection d'officiers par la communauté entière des sciences sociales, et l'accroissement du soutien financier de la part des scientifiques (peutêtre par un système de retenues sur les salaires) à partager avec les associations membres.

Il est probable qu'une répartition similaire des tâches entre les conseils gouvernementaux subventionnaires et les organismes représentatifs de la communauté des sciences sociales s'établirait dans quelques provinces, spécialement entre le Fonds FCAC et l'Association canadienne française pour l'avancement des sciences (ou d'autres organismes académiques) au Québec.

L'une des principales fonctions de la Fédération sera d'améliorer la coordination entre les groupes des secteurs public et privé qui ont des intérêts de recherche. Il n'y a que trop de gens qui prennent des décisions majeures concernant les sciences sociales sans connaissance ni souci des besoins de chacun et de leurs aspirations légitimes.

Bien que cela n'ait rien à voir avec les sciences sociales spécifiquement, il est clair que de meilleures communications et la coopération entre les gouvernements fédéral et provinciaux et le milieu de recherche feraient le plus grand bien à toutes les disciplines. Il est nécessaire d'avoir une certaine forme de relation institutionalisée s'appuie à la fois sur les réalités de la juridiction provinciale et des intérêts nationaux dans le domaine de la recherche. Une possibilité serait un conseil conjoint dont le secrétariat permanent fournirait les études de fond et les consultations publiques.

Cependant, ces deux recommandations sont de type centralisé. Il faut également porter une attention particulière à l'accroissement, à travers le pays, du nombre d'individus et d'institutions qui auront une vaste perspective du développement des sciences sociales. Une solution importante est l'augmentation du nombre d'institutions de recherche financées adéquatement et pleinement opérationnelles. Une deuxième solution serait de réorienter la fonction de doyen de l'administration vers l'avancement des sciences sociales, comme le font certaines grandes universités d'autres pays. Troisièmement, les associations académiques nationales devraient continuellement entreprendre des études de l'état de leur discipline.

\section{Le financement}

Il y a deux principales difficultés dans le financement des sciences sociales: il est insuffisant et les sources sont trop concentrées. Les experts doivent s'efforcer de trouver des sources variẻes de financement auprès des fondations, des provinces, 
des anciens étudiants et du secteur privé. En particulier, des efforts devraient être faits pour éliminer l'insuffisance nette de fonds provenant du secteur privé, en créant une Association de sociétés privées pour la promotion de la recherche, modèle qui existe déjà en Allemagne.

Mais ces sources de financement ne seront pas suffisantes. Aussi loin que nous pouvons voir, la recherche aura vraisemblablement besoin du soutien de l'Etat, en partie à cause de l'économie de succursale qui existe au Canada, en partie à cause du faible taux de population, de l'étendue de la recherche à faire et des territoires à couvrir. À moins que le Canada ne souhaite détruire la renommée de son économie moderne et de sa culture, il est impératif qu'Ottawa et les provinces fassent le nécessaire pour fournir plus de subventions à la recherche et au développement ainsi qu'aux universités, et ce, aux mêmes conditions que les autres pays membres de l'OCDE.

N'importe quel financement additionnel devrait servir au rétablissement des "Programmes d'allocation de dégagement" du CRSSH et au développement des instituts de recherche. Pour améliorer la productivité de la recherche dans ce pays, il faudrait des périodes de recherche ininterrompues, la concentration géographique des lieux de recherche où les chercheurs ayant des intérêts communs sont regroupés et où les ressources nécessaires sont disponibles.

\section{Les institutions et les infrastructures}

Au Canada, les universités fournissent un plus grand pourcentage de recherche en sciences sociales que dans la plupart des autres pays comparables. Il est donc nécessaire que les établissements universitaires de recherche soient aussi compétents que possible et s'efforcent de répondre au vaste spectre des besoins sociaux. Ces objectifs requièrent des changements dans les structures de personnel, de meilleurs liens avec le public et l'amélioration des équipements de recherche. On sait bien que les principaux problèmes de personnel, problëmes qui vont nous hanter pendant des années, sont le manque de rendement, le déséquilibre dans la représentation des deux sexes, et le sous-emploi des diplômés. Voici quatre solutions possibles:

- L'Association canadienne des professeurs d'université, l'Association des universités et collèges du Canada, le Conseil des ministres de l'Éducation, le Secrétariat d'état fédéral et Emploi et immigration Canada devraient immédiatement se concerter pour mettre sur pied et financer des programmes de retraite anticipeje dans les universités. Beaucoup de ces professeurs pourraient travailler à temps plein ou partiel pour les instituts de recherche, les gouvernements et dans le monde des affaires.

- Les femmes devraient avoir la préférence dans les embauches universitaires.

- Les programmes d'études supérieures en sciences sociales devraient être plus orientés vers la préparation des étudiants à des carrières de chercheurs en dehors de l'université.

- La charge de travail des professeurs en sciences sociales devrait 
tenir compte du temps alloué à la supervision des études supérieures, comme cela se fait en sciences naturelles. Ceci améliorerait la recherche et augmenterait les postes d'enseignants.

Eu égard à une meilleure liaison avec le public et à l'amélioration de la recherche appliquée et problématique, les universités pourraient prendre certaines mesures pour perfectionner l'interdisciplinarité, le potentiel de recherche, le développement des disciplines, les échanges et la communication en matière de recherche:

- Les facultés de sciences sociales devraient s'efforcer d'améliorer leurs possibilités de recherche interdisciplinaire et comparative.

- Les comités de promotion et d'octroi de permanence devraient élaborer une politique universitaire soigneuse, supportée par les pairs, qui reconnaîtrait et récompenserait les meilleures activités de vulgarisation et de communication.

- Les résultats de recherche devraient être adaptés à la consommation publique.

- Plus d'universités devraient créer des bureaux de liaison pour la recherche afin de maintenir le contact avec les secteurs publics et privés.

- Soit le Conseil des sciences, soit le Conseil de recherche en sciences sociales et humaines devrait parrainer des études sur l'utilisation des résultats de recherche en sciences sociales par le gouvernement, le monde des affaires et le public.

Finalement, l'analyse des services de recherche et des équipements requis conduit à l'établissement de certaines priorités financières de la recherche pour les années 80. Les plus hautes priorités entrent dans les catégories suivantes:

- Des ressources additionnelles à la disposition des associations, des instituts et des journaux qui sont les principaux "fournisseurs" de services à la recherche.

- Un service complet informatise, multi-dimensionnel, de bibliographie, de documentation et d'abrégés sur les études canadiennes, et ce en liaison avec l'ordinateur principal, probablement fondé sur le "Registre des chercheurs en sciences sociales".

- Une concentration de la recherche de poids dans quelques instituts de calibre mondial, avec des facilités et du personnel de soutien adéquat et à plein temps. Lorsque ceci n'est pas possible ou non désiré, une aide devrait être fournie à des centres nationaux d'information et de documentation dans des secteurs et disciplines définis.

- Un support pour le fonctionnement par "réseau". Ceci comprend de petites conférences, des déplacements, la téléconférence, des réseaux d'ordinateurs, de la consultation et des bulletins de nouvelles.

- Des genres de compilation, de listes et d'accès à la recherche actuelle et à la documentation.

- Des opérateurs et des équipements de bureau d'avant-garde pour une production, une communication et une diffusion efficaces.

- Des subventions d'investissement pour des équipements électroniques sophistiqués de recherche et de formation de chercheurs, 
et des fonds pour accéder aux banques de données et aux systèmes de communication.

- Des subventions accrues pour la publication et la diffusion par des médias électroniques et imprimés.

- Des équipements spécialisés pour des disciplines spécifiques et certains types de recherche (par exemple, la psychologie, la linguistique, l'éducation, l'ạnthropologie et l'archéologie).

\section{La théorie et les méthodes}

Bien qu'abordée en dernier lieu, l'amélioration de la théorie et de la méthodologie en sciences sociales n'est pas le moindre de nos soucis. C'est évidemment la pierre angulaire de tout le reste, et il faut encore beaucoup d'améliorations. Les problèmes sociaux, culturels et politiques récents ainsi que la crise économique mondiale ont douloureusement éprouvé les fondements de la théorie dans toutes les disciplines. Le manque de méthodologie appliquée efficace est connu. Évidemment, ceci n'est pas seulement un problème canadien mais quelques aspects le sont. Un développement "organisé" de théorie et de méthodes est difficile à atteindre. Une grande partie de notre théorie créative vient de penseurs individuels; mais une bonne part aussi a des fondements cumulatifs, et une certaine méthodologie peut être développée collectivement. Pour favoriser le cheminement du procédé, nous pouvons alors imaginer plusieurs initiatives conjointes:

- Les facultés des sciences sociales, la Fédération des sciences sociales et les instituts de recherche devraient multiplier le nombre de conférences et d'ateliers de travail consacrés au développement de la théorie et des méthodes.

- Le CRSSH pourrait promouvoir un programme de développement de la méthodologie appliquée.

- Tous les intéressés, et particulièrement l'Association des études canadiennes, devraient promouvoir la conceptualisation en termes d'expérience canadienne.

- Les experts en sciences sociales ne devraient pas hésiter à s'engager dans des avenues prometteuses qui pourraient triompher des obstacles dans les traditionnelles approches libérales, marxistes, et autres.

\section{Conclusion}

Quelques lecteurs diront que les suggestions ci-dessus sont trop nombreuses et coûteuses, ou qu'elles ne s'accordent pas avec les traditions de laissez-faire et d'individualisme des sciences sociales.

Je pense que nous avons déjà assez de preuves qu'en dépit des grandes réalisations des dernières années, l'histoire montre que les sciences sociales en sont encore au stade embryonnaire. Les futurs développements demanderont des données de base, des analyses longitudinales, la cumulation des résultats, le développement de la théorie et de la méthode, et des études comparatives sur lesquelles nous avons déjà jeté un regard. En même temps, nous avons récem. 


\section{John E. Trent}

ment constaté que les sciences sociales sont une base si importante des connaissances politiques et économiques, et bien évidemment, de la critique sociopolitique, qu'elles ne sont plus de simples préoccupations de chercheurs. Néanmoins, si nous voulons progresser, l'indépendance et la liberté de recherche en sciences sociales doivent être équilibrées par des mécanismes de développement efficaces. Toutes les propositions ci-dessus ont été faites dans cet esprit. 